\title{
WHO IS AFRAID OF THE (BIG BAD) EUROPEAN UNION? EUROPEAN INTEGRATION AND FEARS ABOUT JOB LOSSES
}

\author{
Jonas Grauel, Jana Heine \& Christian Lahusen
}

\section{Introduction}

In 2008, the European Union (EU) enacted the 'Agency Workers Directive' to ensure that workers placed via employment agencies receive the same pay and working conditions as regular and fixed-term employees doing the same work in the same company. This directive was part of the EU's attempts to protect atypical workers, but it was not well received by some governments, particularly the United Kingdom, Ireland, Denmark and Germany. Germany tried to block enactment, arguing that the EU regulations would put many contracts at risk and generate costs for businesses in the range of several billion euros. Companies, employers and national governments have not been alone in voicing concern about the implications of European policymaking. In 2005, trade unions and welfare associations, for instance, opposed the 'Bolkenstein Service Directive', which proposed simplified regulations for the establishment of businesses and provision of cross-border services. Their argument was that liberalization of the service market would endanger service quality, wages and working conditions, particularly in sensitive areas of general welfare provision. Only with substantial changes was the regulation finally passed in 2006 .

These conflicts illustrate the concerns and fears that the EU arouses within the public sphere. Such worries have seemed to increase as the EU receives more competencies in various areas of policymaking. The current financial and monetary crisis, which has nourished anxieties about accelerating rises in costs and pending insolvency of banks and countries, is just one of the recurrent issues that has fed doubts about the magnitude and speed of European integration and their consequences for member states and individual citizens. Fears seem to be part of a subcutaneous storyline of European integration. They thus deserve systematic analysis.

Scholarly writing has committed to this task by studying 'Euroscepticism' (Hooghe \& Marks, 2007), a concept that refers to an attitude of doubt or disbelief in regard to the EU. In order to measure this stance,

(C) University of Siegen, 2013

This is an open-access chapter distributed under the terms of the Creative Commons Attribution-

NonCommercial 3.0 Unported (CC-BY-NC 3.01)dicensee l, Jana Heine, and Christian Lahusen - 9789004261662 
empirical analysis has made extensive use of available survey data, with particular emphasis on the cognitive dimension, such as support of one's own country's EU membership and of further steps towards European integration (e.g., McLaren, 2007; Garry \& Tilley, 2009). A number of factors impinging on sceptical attitudes towards the EU have been identified. Amongst them, at the individual level, are socio-demographic traits (age, gender, social class), collective identities and political orientations; while those at the country level are societal characteristics such as economic growth, unemployment rates and media coverage (e.g., Hooghe, Huo \& Marks, 2007; Lubbers \& Scheepers, 2010). Less emphasis has been put on fears that EU citizens might have in regard to European integration (McLaren, 2004). While fears are partly a consequence of cognitive reflections, assessments and judgements, they are also a more diffuse and emotional sensation involving distrust, discomfort and anxiety. This implies that cognitions and emotions might diverge or even be contradictory. In fact, it is perfectly possible for individuals to be firmly convinced of the merits of the EU, and its advantages for their own country and personal situation, but at the same time be plagued by worries relating to potentially harmful side effects and future European integration.

Public fears are thus an important key to better understand the way the European population views and values the EU, to identify where potential risks may emerge for the further process of European integration, and to decipher the individual and contextual factors that influence sceptical dispositions. These general research objectives translate into the following, more specific questions: Do some issues related to European integration generate more fears than others (e.g., jobs compared to cultural identities)? How do European countries differ in their issue-specific fears about European integration? To what extent can any such differences be explained, respectively, by individual-level factors and by country-level factors?

In order to answer these questions, we draw on scholarly writing and conduct an empirical analysis of data from the 2008 European Values Study (EVS), making use of multilevel analysis. The findings of these efforts largely corroborate previous research, albeit with some modifications and extensions.

\section{Theory and hypotheses}

Research on public support for the EU has become increasingly interested in Euroscepticism, given the growing resistance in many member states 
to further steps towards European integration and enlargement. Defeats of national governments in various EU referenda (e.g., that on the European constitution in 2005 and on the Lisbon Treaty in 2008) have clearly demonstrated an erosion of the 'permissive consensus' that has backed the European integration process during its fifty years. 'Euroscepticism is a potent feature of the political landscape across the European Union' (Hooghe \& Marks, 2007: 119). Scholars have studied these attitudes, distinguishing various dimensions and topics. Much research has been interested in measuring public support for the EU by identifying degrees of scepticism ranging from strong pro-Europeanism to clear opposition (Weßels, 2007). Moreover, research has pointed to various forms of Euroscepticism. Following a general line of study (Easton, 1965, 1975; Dalton, 1999, 2004), authors distinguish between diffuse attitudes towards the EU as a general regime or community and specific forms of doubt and disbeliefs associated with particular policy fields, European institutions and types of political personnel (McLaren, 2004; Krouwel \& Abts, 2007).

Finally, research has distinguished more cognitive forms of Euroscepticism from more emotional ones. Most studies have analysed the more cognitive forms of support, using Eurobarometer questions that ask respondents to indicate their support for giving European institutions more competencies in various policy fields or to weigh the advantages of EU membership (e.g., 'has your country, on balance, benefited from being a member of the EU?' and 'is membership of your country in the EU a good thing?') (McLaren, 2007). Affective stances have also been analysed regarding European identifications and feelings of belonging to Europe (Green, 2000; Díez-Medrano, 2003; Bruter, 2004) and with reference to trust and distrust of fellow European nations (Delhey, 2007). Explicit questions about citizens' fears are less studied (McLaren, 2004). Analysis of this aspect is important, though, to reach a more comprehensive understanding of citizens' concerns about negative implications and consequences of the European integration process. As indicated above, we assume that there is a conceptual and empirical difference between the more cognitive aspect of Euroscepticism analysed in previous studies, and the more emotional dimension at the centre of our own analysis. Hence, this chapter takes up questions of the EVS that aim to measure existing anxieties associated with the general trend of European integration in specific areas of action.

Previous studies on Euroscepticism provide important theoretical and empirical insights to better describe analytical dimensions and explanatory 
factors related to EU-specific fears. In a descriptive perspective, research has demonstrated that Euroscepticism varies across countries. Britain, Sweden, Austria and the Baltic countries are the most Eurosceptic nations, while the Mediterranean EU member states, along with Belgium, Luxemburg and Hungary, are among the most supportive of the EU. Finland, Denmark, the Netherlands, Germany and France exhibit intermediate levels of Euroscepticism (Weßels, 2007: 42f.; Hooghe \& Marks, 2007: 122f.).

For explanatory purposes, scholarly writing has unveiled factors at both the country and the individual level, although the focus has been primarily at the level of individual citizens, in line with most public opinion research. At the individual level, research has highlighted the importance of objective, socio-demographic traits as well as of subjective beliefs and ideas. For instance, it is argued that potential losers of the European integration process will have more sceptical opinions, while winners will defend the EU most ardently (McLaren, 2004: 900; Lubbers \& Scheepers, 2010: 800; also Fligstein, 2008). At the same time, scholars emphasize that Euroscepticism is also determined by the types and strengths of civic attitudes, collective identities, values and levels of generalized trust. Research shows that people with more traditionalist, materialist and ethnocentric beliefs are more sceptical towards the EU (see also Green, 2000; Nelsen, Guth \& Fraser, 2001: 204f.; Boomgarden \& Freire, 2009: 1242f.). Finally, research has stressed the interrelations between the dimensions, as socioeconomic vulnerability is interrelated with more exclusive identities, both of which condition relatively critical attitudes towards the EU (De Vries \& Kersbergen, 2007; Hooghe, Huo \& Marks, 2007: 329).

Apart from these individual characteristics, research acknowledges that Euroscepticism is in part determined by the social reality prevalent in EU member states. This is plausible, given that specific countries tend to be generally more or less sceptical, as highlighted earlier. In regard to contextual factors, a number of arguments have been advanced. Some older, smaller and wealthier member states are found to be more supportive of the EU (Green, 2000: 303; Weßels, 2007). This is because they proactively participated in the building of the EU and recognize the advantages of membership. Countries benefiting from the EU budget and maintaining close trade relations also seem to be more supportive of the EU (Anderson \& Reichert, 1996; Eichenberg \& Dalton, 2007). However, richer and older member states demonstrate greater scepticism if net benefits of EU membership are negative (Eichenberg \& Dalton, 1993; McLaren, 2004) and if labour migration is perceived as a threat (Garry and Tilley, 2009). Hence, socio-economic factors do not seem to influence scepticism in a direct 
and clear way. For this reason, scholars have underlined the mediating impact of the political context, arguing that Euroscepticism is more widespread in countries where political entrepreneurs mobilize against the EU and where the mass media are more critical (Hooghe, Huo \& Marks, 2007: 341; Lubbers \& Scheepers, 2010). At the same time, people identify more with Europe in countries where there is less satisfaction with national politics (Westle, 2003). Finally, cultural traits of member states have been analysed, though generating few conclusive findings. Catholic nations are less Eurosceptic than Protestant ones (Boomgaarden \& Freire, 2009; Nelsen, Guth \& Fraser, 2001), but the effect of religious legacies is not generally a given in an enlarging Europe, and religion seems to lose weight over time (Nelsen, Guth \& Highsmith, 2011). Overall, the picture is thus less conclusive and clear in regard to country-specific factors. Either Euroscepticism is determined by a country-specific set of causes, or contextual factors play a minor role, when compared with individual determinants (Lubbers \& Scheepers, 2010: 811f.).

In sum, research has generated a wealth of insights and ideas to better understand citizens' attitudes towards the EU. However, evidence is still inconclusive. This may be because scholars tend to conceptualize Euroscepticism in quite different ways and have dissimilar explanatory purposes in mind. For these reasons, we propose to focus on one specific dimension of Euroscepticism, namely, on fears voiced regarding the processes of European enlargement and integration. We analyse different areas in which negative consequences for member states are possible: loss of jobs, declines in security, reduced power of the country in the world, loss of national identity and culture, and increased payments to the EU. Our primary interest is not to identify and analyse generalized anxieties across these variables. In fact, we argue that fears vary markedly between the different issue areas. Hence, an analysis of individual issues will help us to develop more reliable explanations of the EU citizenry's fears associated with European integration. In particular, our study centres on EU citizens' worries that the building of the EU might bring about a loss of jobs within their own country. Our explanatory framework consists of three sets of factors, comprising both individual and country-specific traits.

\section{Socio-economic factors}

Our first theoretical assumption is that citizens' fears are determined by the socio-economic features of their country and their own socialstructural position. Here, vulnerability is the explanatory mechanism. 
Individuals at the lower end of the class structure, with a smaller store of socially valued resources (i.e., education and income) and much more limited control over their employment situation, will worry more about a loss of jobs in their country, because labour market displacement is a more immediate and realistic threat to them (McLaren, 2004: 900). In this context, however, we need to take gender into consideration, because the likelihood of fearing the loss of jobs might be distributed differently between men and women, as gender roles typically expect men to be the family breadwinner. In previous studies of Euroscepticism, age turned out to be of no or of little relevance (Garry \& Tilley, 2009; Lubbers \& Scheepers, 2010). Therefore, we control for the effect of age without formulating an explicit hypothesis.

H7. The lower the respondents' position in the social structure in terms of income, education and occupational status, the higher their readiness to be fearful of negative consequences of EU integration for jobs in their countries.

H2. Men are more concerned about the loss of jobs than women.

At the same time, however, we assume that vulnerability is mediated by the socio-economic context of the countries in question. We propose that people are more afraid of job losses in countries with a weaker labour market (i.e., in terms of employment and unemployment rates). In these countries, respondents will be more aware of the societal problem of unemployment, and they will also be more concerned about potential losses of jobs in their country as a consequence of the internal competitiveness of the EU labour market. In economies with stronger and more stable labour markets, citizens will be less fearful of job losses due to European integration, because they will have more trust in the ability of their economy to benefit from the internal market and to buffer detrimental effects.

H3. The lower the employment rate and the higher the unemployment rate of a country, the stronger that country's citizens' fears about the loss of jobs due to European integration.

Formulated in this way, however, there is a chance that the assumed effect of labour markets on fears is a spurious one, because it could be economic performance (e.g., gross domestic product (GDP) per capita) or the cost of labour (e.g., monthly average wages) that actually determines anxieties. In 
this regard, we need to formulate two contrasting assumptions, based on the contradictory findings of previous research. On the one hand, we can argue that people living in countries with strong economic performance and higher wage levels will be more afraid of job losses within the internal market (e.g., due to the relocation of companies to EU countries with lower labour costs). On the other hand, respondents from such countries may be less affected by these anxieties, due to these countries' higher levels of productivity and competitiveness and the economic benefits expected from the European internal market.

H4a. The higher the economic performance and the cost of labour in a country, the lower its citizens' fears about the loss of jobs due to European integration.

H4b. The higher the economic performance and the cost of labour in a country, the greater its citizens' fears about the loss ofjobs due to European integration.

\section{Institutional and political factors}

We also include political-institutional factors in our model. This is because we assume that respondents' fears about the effect of European integration on member states will mirror their confidence in the nation-state and its problem-solving ability. Here again, we include factors at the individual and the country level. In regard to individual traits, we propose that attitudes matter. While attitudes cannot be seen as factors that exert a causal influence on fears, it is still interesting to determine whether they covariate with fears. On the one hand, we suppose that higher levels of institutional trust (i.e., confidence in political, judicial, policy, educational and welfare institutions) correlate with lower levels of anxiety in regard to the loss of jobs. Trustful respondents will thus be more optimistic that the building of the EU will not have harmful effects on their national labour market. On the other hand, we hypothesize that attitudes towards democratic performance are interrelated with fears as well. This means that individuals who are more critical of the problem-solving capacity of democratic systems will also be more inclined to voice concerns about European integration, because they do not believe that elected governments and EU institutions have the capacity and the will to protect national labour markets from harm. In regard to these attitudinal factors, we do not speak of causal effects but rather of correlated factors. 
H5. Institutional trust and confidence in the effectiveness of democracies negatively correlates with fears about the detrimental effects of the $E U$ on national labour markets; that is, more trustful and confident respondents are less fearful and vice versa.

At the aggregate level, we assume that the problem-solving capacity of nation-states is an important contextual factor impinging on citizens' worries. On the one hand, we hypothesize that a strong welfare state dampens individual fears, because it guarantees social security to those affected by joblessness and because it is actively committed to furthering job creation and employability. On the other hand, we propose that government performance and effectiveness can help to explain EU-related fears. Thus, in member states with more effective government, we expect citizens to be less fearful regarding the process of European integration, because these states are better equipped to develop and defend national labour markets within the context of European integration. To test this, we make use of available governance indicators that measure the quality of public service provision, policy formulation and policy implementation.

H6. The stronger the welfare state, the less widespread are fears about the loss of jobs due to European integration.

H7. In countries with a more effective government, citizens have less fear about the detrimental effects of EU integration on national labour markets.

\section{Community-related factors}

Our analysis also ponders the proposition that citizens' worries about job losses might be determined by anxieties related to the erosion of local communities and closed identities. Thus, we argue that ethnocentric and xenophobic attitudes ${ }^{1}$ are a factor to be taken into consideration. These attitudes are related to the socio-economic factors discussed previously, because they define labour as a scarce good and labour markets as competitive arenas where the gains of one side are the losses of the other. Moreover, they reflect a more general concern about external threats to local communities. For this reason, we assume that xenophobic attitudes go hand in hand with concerns about negative implications of the

${ }^{1}$ In the following we use the terms 'ethnocentric' and 'xenophobic' as interrelated dimensions, xenophobia being an outward-looking expression of ethnocentrism. 
European integration process for national labour markets, for example, because the building of the EU is perceived as a threat to closed local communities, as it promotes the free movement of goods and people across countries and localities.

H8. Ethnocentric attitudes are positively related to fears that the EU might bring about a loss of jobs within countries.

At the country level, we need to determine whether immigration rates help to explain EU-related fears. Following research on ethnic prejudices and residential preferences (Semyonov, Glikman \& Krysan, 2007), it might be expected that higher numbers of migrants provide a more fertile context for the articulation and diffusion of xenophobic attitudes. They may thus be an indirect asset for Eurosceptic opinions. However, the opposing assumption is plausible as well: higher migration rates could be associated with less fear, because societies with more migrants provide more opportunities for intercultural contacts and exchanges. These assumptions are simplistic, because even in countries with a large share of immigrants, intercultural exchanges do not take place in segregated societies. However, since no country-level measure for ethnic segregation is readily available, we use immigration rate instead.

Hga. The higher the immigration rate of a country, the less its citizens fear the loss of jobs due to European integration.

Hgb. The higher the immigration rate of a country, the more its citizens fear the loss of jobs due to European integration.

\section{Data and measurements}

The data in this investigation were drawn from the 2008 wave of the EVS. Of the 47 countries taking part in the EVS, only those that were EU member states are included in the analysis. This restriction is due to our research question, because fears associated with the building of the EU mean completely different things in member and non-member states. Respondents from Northern Ireland and the United Kingdom were treated as members of one national unit. ${ }^{2}$ Furthermore, cases without a

${ }^{2}$ Northern Cyprus was treated as a non-EU member and excluded from the dataset. 
valid ISCO 88 code $^{3}$ were excluded from the dataset to ensure that all respondents could be assigned to a social class. A total of 34,470 cases were left for inclusion in our analysis. ${ }^{4}$

To analyse people's fears in relation to the processes of European integration and enlargement, data were taken from seven EVS items. In regard to European integration, respondents were asked on a 10-point scale the extent to which they fear that the process of European integration will lead to a loss of social security, of jobs, of national identity and culture, of their own country's power in the world, and a situation in which their own country will have to pay more and more to the EU. An additional question asked respondents to indicate on a 10-point scale whether European enlargement should continue or has proceeded too far. Finally, we constructed a 'fear index' by summing the scores of the first five items (without the European enlargement question). However, this index was used only for descriptive purposes. For the explanatory objectives we focused on a specific fear item: the loss of jobs. This question was chosen as the dependent variable in our multilevel models, because theoretical assumptions and empirical findings underline that anxieties in regard to the EU are dependent on the issue or field at stake, and the loss of jobs is the most widespread anxiety within our sample.

In regard to the individual-level factors, we operationalized our research assumptions with the following variables. First, we measured the socialstructural position of the respondents and their socio-economic vulnerability by the level of educational attainment and the monthly household income in euros corrected for purchasing power parity. To analyse the influence of social class, we used the eight-class version of Daniel Oesch's (2006) schema based on differences in the work logic. Assuming that the level of vulnerability roughly increases from the former to the latter ones, we distinguished between self-employed professionals and large employers, small business owners, (junior) managers, technical (semi-) professionals, social-cultural (semi-) professionals, office clerks,

3 The ISCO 88 code is the most recent version of the International Standard Classification of Occupations (see www.ilo.org/public/english/bureau/stat/isco/index.htm).

4 The excluded cases are unequally distributed across the countries. The share of missing cases ranges from 5.8\% (France) to $31 \%$ (Romania). The main reason for the exclusion of cases was a missing ISCO 88 code. By comparing descriptive statistics of the complete EVS dataset with our reduced dataset, we determined whether missing cases had any substantial effect on the distribution of the variables in our models. In some countries, the mean for age is four years higher in our dataset than in the full sample, but as we will see age is not a significant explanatory factor. For all other variables of interest, the differences are negligible. 
service workers and production workers (Oesch \& Rennwald, 2010). ${ }^{5}$ Second, we developed two index scales to operationalize the politico-institutional factors described above. ${ }^{6}$ On the one hand, we computed an index that measures institutional trust by considering how much confidence respondents have in a number of institutions: the educational system, police, parliament, civil service, social security, the health care system, the justice system, political parties and government. On the other hand, we built an index that summarizes the opinions of citizens in regard to the performance of the democratic system. The following variables were used for this purpose: 'democracy causes bad economy', 'democracy is indecisive', and 'democracy cannot maintain order'. Thirdly, we developed an index to measure xenophobic feelings based on a series of questions devoted to attitudes towards migrants. ${ }^{7}$ Here, we selected items stating that immigrants 'take away jobs from [nationality]', 'undermine the country's cultural life', 'increase crime problems', 'are a strain on welfare system', and 'will become a threat to society'. Higher scores in these index scales mean (1) higher rates of institutional trust, (2) more sceptical opinions on the performance of democracies and (3) more outspoken xenophobic attitudes. ${ }^{8}$

At the country level, we retrieved data on different explanatory factors for all 27 member states. ${ }^{9}$ For socio-economic traits, we took the GDP per

5 To address changes in the employment structure due to service sector growth, welfare state expansion and higher female participation rates, Oesch (2006) developed a new class scheme. It accounts for greater heterogeneity within the waged middle class concerning political behaviour as well as for the dissolution of barriers between manual and nonmanual work. It is a combination of both the horizontal differentiation of work logics (e.g., organizational work logic, inter-personal service work logic) and the hierarchical dimension of employment relationships depending on employees' marketable skills.

6 To build the indices, the sum score of a range of original item values was divided by the number of items used to construct the score. The selection of items for the indices was based on exploratory factor-analyses. Items loading high on contextually relevant factors were tested for reliability. All indices show good values of Cronbach's alpha ranging from 0.79 to 0.87 .

7 See previous footnote.

8 Missing values are a problem for multilevel models since the statistical fit of nested models can only be compared if the case basis is constant for all models. The SPSS multiple imputation procedure was used to deal with missing values. Linear regressions were used as imputation procedure for metric and pseudo-metric variables (10-point scales). The indices - which are based on sum scores of several items measured with ordinal 4-point scales - were computed on the basis of the original data, and then the index as a whole was interpreted as a pseudo-metric variable and imputed with linear regressions.

9 The following data sources were used: Data on GDP was obtained from the International Monetary Fund (http://www.imf.org/external/pubs/ft/weo/2011/o1/weodata/index .aspx). Data for employment and unemployment rates and social expenditures per capita 
capita adjusted for purchasing power parity and average monthly wages as an indicator of socio-economic performance. Employment ${ }^{10}$ and unemployment rates were applied to measure the strength of labour markets. Concerning the institutional and political factors, we used information on social expenditures per capita and the coverage rate of unemployment benefits to measure the strength of the welfare state. Moreover, we made use of the Governance Matters Index of the World Bank in order to gauge the degree of government effectiveness in our 27 countries. ${ }^{11}$ Finally, we used data on the proportion of immigrants ${ }^{12}$ in the general population. Given that the survey was conducted between 2008 and 2010, at different times in different countries, we gathered data on these factors for the year the survey was conducted in that country. This was done to neutralize effects of time in a context marked by economic and financial crisis.

\section{Results}

We begin by presenting descriptive scores for the six dependent variables averaged at the country level for all $27 \mathrm{EU}$ member states. These analyses are followed by a presentation of the multilevel regression models, which enables us to investigate the explanatory power of individual and contextual-level factors at the same time.

\section{Country differences in regard to fears: Comparison of means}

To get a first impression of the level of fears in each country, we computed an index comprising the five dependent variables, and plotted it against

was obtained from Eurostat (http://ec.europa.eu/eurostat). Data on unemployment benefits and average monthly wages was taken from the United Nations Economic Commission for Europe (UNECE) /http://w3.unece.org/pxweb/dialog/). For immigrant rates, data from 2005 was used, obtained from Eurostat and the World Bank (http://search.worldbank.org/ data?qterm $=$ migration \&language $=\mathrm{EN} \&$ format $=$ html $\&-\mathrm{os}=0$ ).

10 Employment was measured by the rate of labour force participation of all employable adults.

11 The index 'government effectiveness' measures perceptions of the quality of public and civil services, the degree of independence from political pressures, the quality of policy formulation and implementation, and the credibility of the government's commitment to such policies. These indicators are based on statistical compilation of responses given by a large number of enterprises, citizen and expert survey respondents in the countries (Kaufmann, Kraay \& Mastruzzi, 2010).

12 Measured as the international migrant stock, which is the number of people born in a country other than that in which they live, including refugees. 


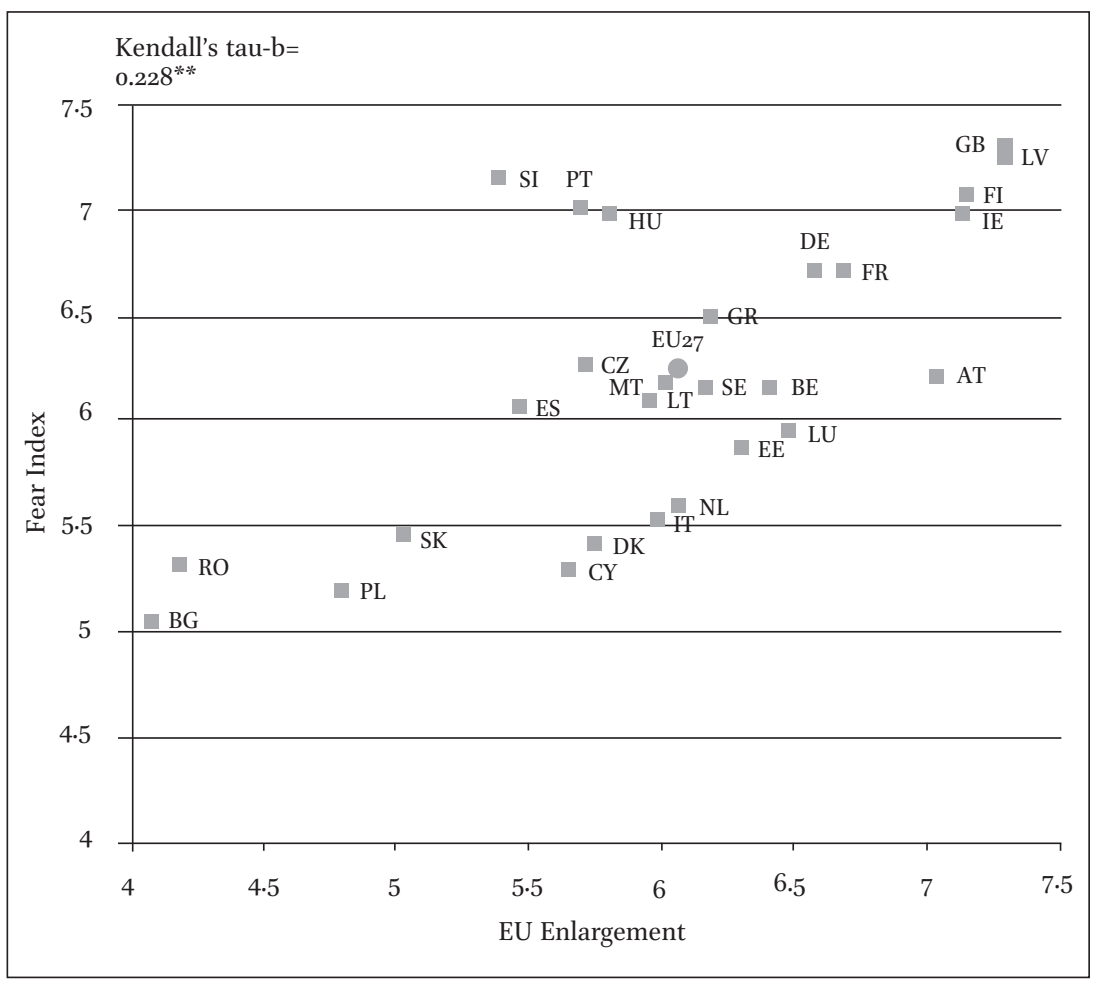

** $p<0.01$ (two-sided).

Figure 2.1. Means of fear index and EU enlargement for all EU member states

the question asking respondents to state their opinion about the enlargement of the EU. Figure 2.1 shows in general that the items are moderately correlated. Citizens of countries that are less fearful in regard to European integration also support further enlargement, and this is true particularly for Bulgaria, Romania, Poland and Slovakia, although these countries are more worried about integration than about enlargement. Citizens of countries that are more strongly concerned about integration oppose further enlargement. This applies to Great Britain, Latvia, Ireland and Finland. However, there are exceptions to this picture. Some countries, like Slovenia, Portugal and Hungary, exhibit above average fears that the process of European integration will have some sort of negative consequences for the country, but they do not oppose further enlargement of the EU. At the same time, countries such as Austria, Luxembourg, Estonia and Belgium express stronger reluctance to further steps towards EU enlargement, but they are less afraid of the European integration process. 
The first apparent result is that no clear geographic pattern emerges from these figures. That is, there is no North-South or East-West divide. The findings even diverge from the picture portrayed in previous studies on Euroscepticism (e.g., Weßels, 2007). This supports our initial assumption that there is a conceptual and empirical difference between the more cognitive and the more emotional dimension of Euroscepticism. While some countries conform to the expectations (e.g., the UK and Latvia as sceptical and fearful countries), this is not the case in many others. Many countries are either more afraid than expected (e.g., Hungary, Ireland and Portugal) or less fearful (e.g., Poland, Denmark and the Slovak Republic). These findings might mirror changes over time. However, it is more probable that a supportive position towards the EU does not exclude a more fearful stance towards European integration and enlargement, and vice versa.

The general picture of fears in the EU is corroborated when looking at the means of the single fear items. Table 2.1 shows the average of fears across all countries and the extent to which member states deviate from these means. Positive values indicate an above-average level of fear among a country's citizenry, while negative values indicate fears below the average for the EU-27. In regard to the East European member states, it is especially Latvia, Slovenia and Hungary that show consistently high scores on the fear variables, whereas Bulgaria and Romania as well as Poland repeatedly present below-average scores. Other East European countries show a slight tendency to be among those countries that are less afraid of the consequences of European integration.

Looking at the individual items, European citizens tend to be more fearful of the economic consequences of European integration, in particular, harmful effects on the national labour market. They are less concerned about the loss of power and cultural identities. These worries reflect the fact that European integration has focused most strongly on the creation of the single market and monetary union. Moreover, the table shows that most countries tend to be either more optimistic or pessimistic than the average. This is the case, for instance, for Great Britain, which is among the countries with the highest fear levels for all items and even heads the list twice-first in connection with 'loss of power' and second in relation to 'loss of national identity/culture'. However, for other European countries, the results are issue-dependent. Most of these countries are less afraid than the average, but tend to be more worried with regard to specific topics: Austria about jobs and social security, Belgium about social 
Table 2.1. Fears: Means and deviations from means for all EU member states

\begin{tabular}{|c|c|c|c|c|c|c|c|}
\hline Country code & $\begin{array}{c}\text { EU } \\
\text { enlargement }\end{array}$ & $\begin{array}{c}\text { Fear } \\
\text { index }\end{array}$ & $\begin{array}{l}\text { Loss of } \\
\text { social } \\
\text { security }\end{array}$ & $\begin{array}{c}\text { Loss of } \\
\text { national } \\
\text { identity/ } \\
\text { culture }\end{array}$ & $\begin{array}{c}\text { Own } \\
\text { country } \\
\text { pays } \\
\text { more }\end{array}$ & $\begin{array}{l}\text { Loss of } \\
\text { power }\end{array}$ & $\begin{array}{c}\text { Loss of } \\
\text { jobs }\end{array}$ \\
\hline EU-27 & 6.06 & 6.24 & 6.17 & $5 \cdot 73$ & 6.74 & $5 \cdot 71$ & 6.83 \\
\hline Austria & 0.97 & -0.03 & 0.24 & -0.10 & -0.02 & -0.43 & 0.21 \\
\hline Belgium & 0.35 & -0.08 & 0.41 & -0.20 & -0.35 & -0.20 & -0.11 \\
\hline Bulgaria & -1.98 & -1.19 & -1.85 & -1.20 & -0.61 & -0.77 & -1.08 \\
\hline Cyprus & -0.41 & -0.95 & -1.27 & -0.86 & -1.14 & -1.16 & -0.14 \\
\hline Czech Republic & -0.34 & 0.03 & 0.25 & 0.19 & 0.04 & 0.19 & $-0.5^{1}$ \\
\hline Denmark & -0.31 & -0.82 & -0.87 & -0.19 & -0.96 & $-0.5^{1}$ & -1.58 \\
\hline Estonia & 0.24 & -0.37 & -0.41 & $-0.3^{2}$ & -0.16 & -0.65 & -0.31 \\
\hline Finland & 1.09 & 0.83 & 0.63 & $0.5^{0}$ & 0.76 & 1.11 & 1.09 \\
\hline France & 0.62 & 0.48 & 0.92 & $0.5^{6}$ & 0.19 & $0.5^{1}$ & 0.23 \\
\hline Germany & $0.5^{2}$ & 0.47 & 0.96 & -0.01 & 0.53 & -0.20 & 0.98 \\
\hline Greece & 0.12 & 0.25 & 0.02 & $0.5^{0}$ & -0.08 & 0.26 & 0.51 \\
\hline Hungary & -0.26 & 0.74 & 0.86 & 0.11 & 0.73 & $0.5^{1}$ & 1.46 \\
\hline Ireland & 1.07 & 0.75 & 0.14 & 1.09 & 0.12 & 1.35 & 0.89 \\
\hline Italy & -0.07 & -0.71 & -0.62 & -0.46 & -1.21 & -0.76 & -0.41 \\
\hline Latvia & 1.23 & 1.00 & 1.15 & $0.5^{2}$ & 1.05 & $0.5^{6}$ & 1.76 \\
\hline Lithuania & -0.11 & -0.14 & -0.60 & -0.25 & 0.26 & -0.41 & 0.25 \\
\hline Luxembourg & 0.42 & -0.29 & 0.03 & -0.27 & -0.39 & -0.62 & -0.12 \\
\hline Malta & -0.04 & -0.06 & -0.32 & 0.14 & -0.13 & 0.27 & -0.30 \\
\hline Netherlands & 0.01 & -0.64 & -0.83 & -0.54 & -0.21 & -0.28 & -1.27 \\
\hline Poland & -1.26 & -1.04 & -0.92 & -1.14 & -0.80 & -0.73 & -1.48 \\
\hline Portugal & -0.36 & 0.77 & 1.19 & & 0.63 & 0.72 & 1.11 \\
\hline Romania & -1.88 & -0.92 & -1.47 & -0.86 & -0.63 & -0.61 & -1.07 \\
\hline Slovak Republic & -1.03 & -0.79 & -0.25 & -0.89 & -0.42 & -1.19 & -1.19 \\
\hline Slovenia & -0.67 & 0.91 & 1.08 & 0.95 & 1.16 & 0.37 & 1.00 \\
\hline Spain & -0.59 & -0.18 & -0.05 & 0.37 & -0.68 & 0.29 & -0.64 \\
\hline Sweden & 0.10 & -0.08 & 0.14 & -0.27 & 0.25 & 0.40 & -0.62 \\
\hline Great Britain & 1.23 & 1.07 & 0.20 & 1.55 & 0.95 & 1.53 & 1.05 \\
\hline
\end{tabular}

security, Lithuania about jobs and payments to the EU, Malta and Spain about national culture and power, and Sweden about social security, payments to the EU and national power. Germany, in contrast, tends to be more afraid in general, except for the loss of power, where citizens are more confident than the average.

Overall, the data on individual fears reveals no clear pattern. Differences do not follow a divide between new or old member states, or between traditionally Eurosceptic and EU-friendly countries. What then are the factors impinging on or interrelating with anxieties regarding the EU? To answer this question, we need to look closer at the data, both individual-level and country-specific factors. 


\section{Explaining differences: Multilevel analysis}

In a first step we calculated Model 0 -which is the intercept-only model - for each of the dependent variables. The intercepts reveal higher fear scores on the scales related to economic consequences and lower fear scores towards expected negative implications for national identity and culture. ${ }^{13}$ We also calculated the intraclass correlations, which show the percentage of variance explained by the group structure, in our case the countries. The proportion of the overall variance explained at the country level varies considerably between the dependent variables: it is lowest in the case of national identity/culture $(4.8 \%)$, own country pays more $(5.5 \%)$ and loss of power in the world (5.7\%); higher in the case of loss of social security (7.4\%) and EU enlargement (8.9\%); and highest in the case of the loss of jobs (10.2\%). Fears associated with the labour market are not only most widely shared by citizens of the EU, but they also exhibit the highest variance at the country level. Thus, this is the most interesting and enlightening dependent variable for multilevel analysis.

Table 2.2 summarizes the findings of our explanatory models. To achieve a transparent and parsimonious model, we included only variables that showed significant effects and improved the model fit in a substantial manner. ${ }^{14}$ Model 1 identifies a number of predictors at the individual level that impact the likelihood of European citizens being worried about the loss of jobs in their country due to the process of European integration. Most of our general research assumptions are corroborated. Fears are significantly associated with the socio-economic situation of the respondents, with their attitudes towards political institutions and with ethnocentric opinions. However, not all factors are equally important. In regard to socio-demographic characteristics, there is neither a linear nor a U-shaped effect of age on fears, while gender does have a significant

13 The intercepts are as follows, ranked from the highest to the lowest score: 6.82 for the loss of jobs, 6.70 for payments to the EU, 6.13 for the loss of social security, 6.01 for EU enlargement, 5.71 for the loss of national identity and culture, and 5.0 for the loss of power in the world. All intercepts are highly significant $(p<0.001)$.The numbers diverge only slightly from the means in Table 2.1 , due to the fact that intercepts are computed as means of means.

14 All of the other variables mentioned were of course tested, but excluded from the model when they turned out to be of no relevance. At the individual level, this was the case for age. At the country level, the following measures were excluded: employment rates, GDP per capita, average wages, social expenditures per capita, coverage of unemployment benefits and immigration rates. 
effect: men are more concerned than women. $\mathrm{H}_{2}$ is thus corroborated by our data, probably because of a traditional breadwinner model of gender roles and working relations. Socio-economic vulnerability plays a role too, because those with lower levels of household income have more fears than those with a better income, and citizens with a lower educational attainment are more worried than those with higher attainment. Education makes the biggest difference with regard to the socio-economic situation of respondents. On average, individuals with a bachelor's or master's degree score 0.75 points lower on the 10-point scale measuring fear of loss of jobs than citizens with pre-primary education only; respondents with a $\mathrm{PhD}$ scored 0.9 points lower. Looking at the worries of different social classes, fears decrease considerably when moving up the social hierarchy: managers are almost 0.4 points less concerned about the loss of jobs than service workers. Large employers and self-employed professionals, such as firm owners and lawyers, are almost half a point less fearful. While it is largely the hierarchical dimension of the class scheme that accounts for different levels of fear, the horizontal dimension discriminates only between class groups with higher marketable skills. Among the class groups with lower marketable skills-service workers, production workers and office clerks - there are no significant differences. Thus, the assumed impact of the respondent's social-structural position (H1) is corroborated.

Regarding attitudes, our hypotheses 5 and 8 are corroborated. Standardized coefficients were used to compare the strength of the correlations. As expected, low levels of institutional trust are related to more marked anxieties. The same is true for respondents' assessment of democracy's performance: citizens who are critical of the problem-solving ability of a democratic system are also more afraid that the EU will lead to lower levels of employment. Hence, $\mathrm{H}_{5}$ is verified by the data. However, the strongest correlation is that between fears and ethnocentrism. In terms of standard deviation, fears are almost four times more closely correlated with xenophobic attitudes than with institutional trust. Hence, xenophobic sentiments are present in the European citizenry, and are closely linked with attitudes towards the EU (H8).

Model 1 reduces deviance in a significant and substantial manner, demonstrating that socio-demographic factors have an effect on EU-related fears in the realm of jobs, while certain attitudinal factors go along with fears. However, the explanatory power is not very strong at the individual level $\left(r^{2}=0.14\right)$. At the country level, some variance is explained as well $\left(r^{2}=0.12\right)$. This share goes back to a composition effect, because the 


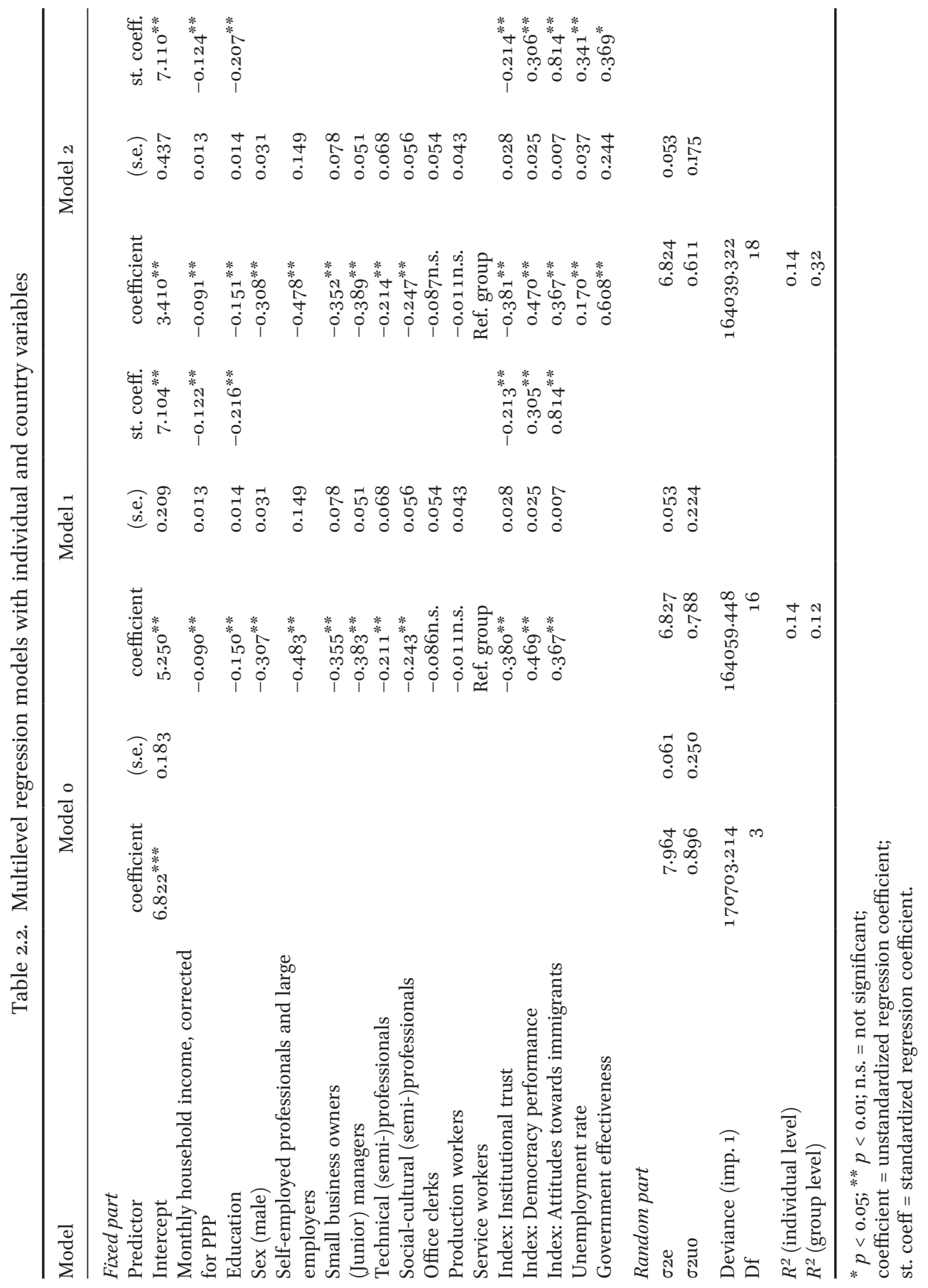


populations of the countries differ along the variables included in the model. In order to improve the predictive force and find out about context effects, we introduce the aggregate level traits of the various countries, as identified in Model 2. In fact, it makes sense to assume that the concerns that citizens have about negative effects of the EU on the job situation depend on the socio-economic and institutional context they live in. For this purpose, we included a series of factors ranging from the GDP and social expenditures per capita to governance performance indicators and the net rate of immigration.

Our calculations demonstrate that only two factors at the national level have a significant effect on job-related fears. The first is the country's unemployment rate, and the second is the government's effectiveness in terms of the quality of public services and the strength of policy formulation and implementation. It is noteworthy that none of the other factors enunciated above had a significant effect in improving the model fit. ${ }^{15}$ That is, most traits of the socio-economic context are irrelevant, and this means that a number of hypotheses are completely or partly refuted. As such, we cannot corroborate the assumption that residents of states with a stronger economy are also more or less afraid that the EU will cause a loss of jobs ( $\mathrm{H}_{4} \mathrm{a}$ and $\left.\mathrm{H}_{4} \mathrm{~b}\right)$. The same is true in regard to institutional factors related to welfare systems; that is, more benevolent welfare states in terms of social expenditures and unemployment benefits do not exhibit lower levels of fears among their citizens (H6). Finally, the proportion of immigrants in the general population has no effect on anxieties (H9a and $\mathrm{Hgb}$ ). Hence, although xenophobic attitudes are the most important predictor at the individual level, this effect is completely unrelated to the objective reality in that country, in the sense that ethnocentrism is closely linked to Euroscepticism even in countries with low levels of migration.

As mentioned before, only two traits of the socio-economic and institutional context make a significant difference. Thus, we can confirm that the situation of the national labour market makes a difference in regard to job-related fears $\mathrm{H}_{3}$ ), however, only in regard to unemployment (see Table 2.2). In fact, the unemployment rate (i.e., the percentage of the labour force in registered joblessness) varies between $3 \%$ and $11 \%$ in our $27 \mathrm{EU}$ member states. As the coefficient shows, an increase of unemployment by

15 These factors were GDP per capita, rate of labor force participation, social expenditures as percentage of GDP, social expenditures per capita, social expenditures on unemployment as percentage of social benefits, and the international migrant stock as a percentage of the general population. 
one percentage point causes an increase of fear of EU-caused job losses of 0.17 points at the country level. Hence, respondents seem to take the situation of the labour market into consideration when they assess the potential effect of the EU on their country. In countries without an inclusive labour market, citizens seem to be afraid that the EU will endanger jobs, while citizens of countries with a more inclusive labour market seem to trust that their economy will successfully master and perhaps even benefit from the European common market and its internal competitiveness.

Nonetheless, one factor of the political and institutional context plays a considerable role in predicting country-specific levels of EU-related fears: governance effectiveness $\left(\mathrm{H}_{7}\right)$. Surprisingly, the hypothesis is refuted as formulated. Good government performance does not reduce the level of fears regarding the loss of jobs. On the contrary, the effect is in the opposite direction: residents of countries with a lower quality of public services and weak policy formulation and implementation are less fearful of the detrimental effects of European integration on the national labour market. Comparing the standardized coefficients, we see that this effect is as strong as the impact of the unemployment rate, although the significance level is a bit lower. Bulgaria, Romania, Italy and Poland, for instance, are the countries with the lowest levels of government effectiveness, according to the Governance Matters Index. They are also countries in which the population is less afraid of detrimental effects of European integration on the job situation. The picture is less coherent in regard to countries with better governance performance, but still a number of these countries (e.g., Finland, France, Germany, Ireland and the United Kingdom) report higher levels of fear.

The explanatory power of the overarching model is satisfactory, given that the two contextual factors explain $32 \%$ of the variance at the aggregate level. Lower unemployment rates reduce public anxieties related to the process of European integration. A similar effect is found for government effectiveness, as countries with a weaker performance of national authorities also demonstrate a lower propensity to be afraid of the EU in regard to national affairs.

\section{Conclusion and discussion}

This chapter examined attitudes of European citizens towards the EU. Taking up previous research on Euroscepticism, it focused on potential fears associated with the EU and the process of European integration. 
In particular, we strived to find out if citizens are concerned about negative effects of the EU on the situation in their own country, and if their assessments varied across different issue areas (e.g., economy, labour market, culture, social security and politics) and between countries. Finally, we were interested in explaining differences with reference to factors at the individual and country levels. Based on data from the $2008 \mathrm{EVS}$, we found that European citizens are not unconditionally worried about the building of the EU. First, concerns about the negative effects of the EU on member states vary considerably between different issue areas. On average, citizens worry more about economic consequences (i.e., loss of jobs, more payments to the EU) than about cultural and political ones (i.e., loss of culture/identity and of power in the world). At the same time, there are more optimistic countries (e.g., Bulgaria, Poland, Romania, Denmark and the Slovak Republic) and pessimistic member states (e.g., Great Britain, Latvia, Slovenia, Finland and Portugal). Interestingly, these groups are quite heterogeneous and do not conform to any clear geographical, political or social divide (e.g., along a North-South or East-West axis). Consequently, the phenomenon of EU-related fears and deciphering their causes and conditions would seem a particularly intriguing one.

Second, we focused on the anxiety that is most strongly stated: the loss of jobs due to the process of European integration. We developed an explanatory model that consisted of individual and country-level factors, and which distinguished between socio-economic, political-institutional and community-related variables. At the individual level, we verified most of the assumptions identified in previous analyses of Euroscepticism. Gender, household income, education and, overall, social class are important factors explaining why people fear the loss of jobs due to European integration. While fears vary systematically with social position, it must also be stated that only a minor share of the variance at the individual level was explained by classical sociological variables. Thus, it has to be considered that fears do not translate simply from objective criteria. Furthermore, fears accompany certain kinds of attitudes. Of utmost importance are xenophobic opinions, which are strongly associated with anxieties about detrimental effects of European integration. Moreover, low levels of institutional trust and scepticism in regard to the performance of democratic systems go hand in hand with EU-related fears.

At the country level, we observed that the effect of the societal context was not generalized, as most socio-economic and institutional traits of EU member states (e.g., economic performance, average monthly wages, social expenditures and immigrant rates) had no impact on fears. Only two 
contextual variables were decisive. First, national unemployment rate was a significant factor, meaning that citizens take the labour market situation into consideration when evaluating the potential impact of the EU on their country. Second, the quality of public services and the strength of policy formulation and implementation made a difference. Countries with poor government effectiveness were less worried about the impact of the EU on the national labour market than countries with a better performance. Third, while xenophobic attitudes were strongly intertwined with EU-related fears, the net rates of immigrants within the population had no effect whatsoever on these anxieties. That is, ethnocentrism is part and parcel of Euroscepticism, even in countries with relatively few immigrants. It is thus a factor to be taken into consideration regardless of the member states involved.

Based on these findings, we can conclude, first of all, that European citizens do not voice a generalized, amorphous and diffuse fear about the potential consequences of the EU on their own country. Undoubtedly, we can distinguish more pessimistic and optimistic countries, and more and less worried population groups. However, most fears relate to specific issue areas, and these issue-related fears diverge considerably and consistently, illustrating that European citizens differentiate and prioritize their concerns. Indeed, they worry more about the economic consequences of EU membership than about the impact on social security systems, and they worry much less about effects on national cultures and identities. Moreover, we revealed not only that EU-related fears are issue-specific. Additionally, individuals turned out to be rather sensitive to the specific context and situation in which they live. In fact, European citizens look at the immediate labour market situation when assessing the potential impact of the EU on the national job market. Moreover, citizens' fears tend to mirror the specific social-structural position they find themselves in. The greater their vulnerability, the more inclined they are to fear for detrimental consequences of European integration. Certainly, it is to be expected that these groups will be more worried about the loss of jobs in general. However, it is also important to note that they blame the EU for this. At the same time, our data corroborates the hypothesis that more privileged social classes are less fearful about the EU, because managers, large employers and self-employed professionals are better able to control their employment and to benefit from the free movement of capital, goods, services and labour within the EU.

The second conclusion to be drawn is less flattering for the EU. In regard to individual attitudes, citizens who trust more in their national 
institutions and are more convinced that democracy is an effective form of governing and solving problems tend to worry less about the detrimental effects of the EU. It is plausible that such citizens trust in the capacity of their nation-state to mediate and buffer any potential harm. However, the contextual factors tell a different story. Worries are less widespread in countries with weaker government performance. Citizens of these countries seem either to believe that the EU can only improve the labour market situation in their country, or they think that the EU is unable to do any additional harm. Countries with better government performance are more fearful of detrimental effects of European integration, although the pattern is less clear. Citizens seem to be more afraid if their country's labour market has more to lose than to gain from European integration. These worries need to be taken seriously, as they are quite widespread in many of the older and more influential member states, even those that support the EU in general terms.

The economic and financial crisis that is troubling the European member states since 2008 is progressively aggravating public dissatisfaction with the EU. The EVS data, collected during the first year of crisis, give first indications about these anxieties. Basically, our analyses and our conclusions demonstrate that citizens' worries are issue-specific and context-dependent. People in Europe are particularly worried about economic implications of the building of the EU, in particular, about the loss of jobs. Furthermore, they tend to take into consideration their own social-structural vulnerability and the severity of unemployment in their country when voicing their fears. This insight has implications for the EU. If worries are not diffuse and ill-defined, but rather, specific and context-dependent, this means that the EU and its member states are in a position to take action to convince their citizens that the process of European integration will or will not be detrimental to their countries. In times of severe financial crisis and economic strain, this insight is to be taken even more seriously. Ultimately, this means that the EU has to constantly prove its value.

\section{References}

Anderson, C.J. \& M.S. Reichert. 1996. Economic benefits and support for membership in the EU: A cross-national analysis. Journal of Public Policy, 15 (3), 231-249.

Boomgarden, H.G. \& A. Freire. 2009. Religion and Euroscepticism: Direct, indirect or no effects? West European Politics, 32 (6), 1240-1265.

Bruter, M. 2004. On what citizens mean by feeling 'European': Perceptions of news, symbols and borderless-ness. Journal of Ethnic and Migration Studies, 30 (1), 21-39. 
Dalton, R.J. 1999. Political support in advanced industrial democracies. Pp. 57-77 in P. Norris (Ed.), Critical Citizens: Global Support for Democratic Government. Oxford: Oxford University Press.

— 2004. Democratic Challenges, Democratic Choices: The Erosion of Political Support in Advanced Industrial Democracies. Oxford: Oxford University Press.

De Vries, C. \& K. van Kersbergen. 2007. Interests, identity and political allegiance in the European Union. Acta Politica, 42 (2), 307-328.

Delhey, J. 2007. Do enlargements make the European Union less cohesive? An analysis of trust between EU nationalities. Journal of Common Market Studies, 45 (2), 253-279.

Díez-Medrano, J. 2003. Framing Europe: Attitudes to European Integration in Germany, Spain and the United Kingdom. Princeton: Princeton University Press.

Easton, D. 1965. A Framework for Political Analysis. Englewood Cliffs, N.Y.: Prentice Hall.

- 1975. A re-assessment of the concept of political support. British Journal of Political Science, 5 (4), 435-457.

Eichenberg, R.C. \& R.J. Dalton. 1993. Europeans and the European community: the dynamics of public support for European integration. International Organization, 47 (4), 507534 .

- 2007. Post-Maastricht blues: The transformation of citizen support for European integration, 1973-2004. Acta Politica, 42 (2), 128-152.

Fligstein, N. 2008. Euroclash: The EU, European Identity, and the Future of Europe. Oxford: Oxford University Press.

Garry, J. \& J. Tilley. 2009. The marcoeconomic factors conditioning the impact of identity on attitudes towards the EU. European Union Politics, 10 (3), 361-379.

Green, D.M. 200o. On being European: The character and consequences of European identity. Pp. $292-322$ in M.G. Cowles \& M. Smith (Eds.), The State of the European Union: Risks, Reform, Resistance, and Revival. Oxford: Oxford University Press.

Hooghe, L. \& G. Marks. 2007. Sources of Euroscepticism. Acta Politica, 42 (2), 119-127.

Hooghe, L., J.J. Huo \& G. Marks. 2007. Does occupation shape attitudes on Europe? Benchmarking validity and parsimony. Acta Politica, 42 (2), 329-351.

Hox, J.J. 2010. Multilevel Analysis: Techniques and Applications, New York, NY: Routledge.

Kaufmann, D., A. Kraay \& M. Mastruzzi. 2010. The worldwide governance indicators: A summary of methodology, data and analytical issues. World Bank Policy Research, Working Paper No. 5430, [http://papers.ssrn.com/sol3/papers.cfm?abstract_id=1682130, last access: 17.2 .2012$]$.

Krouwel, A. \& K. Abts. 2007.Varieties of Euroscepticism and populist mobilization: Transforming attitudes from mild Euroscepticism to harsh Eurocynism. Acta Politica, 42 (2-3), $252-270$.

Lubbers, M. \& P. Scheepers. 2010. Divergent trends of Euroscepticism in countries and regions of the European Union. European Journal of Political Research, 49 (6), 787-817.

McLaren, L. 2004. Opposition to European integration and fear of loss of national identity: Debunking a basic assumption regarding hostility to the integration project. European Journal of Political Research, 43 (6), 895-911.

- 2007. Explaining mass-level Euroscepticism: Identity, interests, and institutional distrust. Acta Politica, 42 (2), 233-251.

Nelsen, B.F., J.L. Guth \& C.R. Fraser. 2001. Does religion matter? Christianity and public support for the European Union. European Union Politics, 2 (2), 191-217.

Nelsen, B.F., J.L. Guth \& B. Highsmith. 2011. Does religion still matter? Religion and public attitudes toward integration in Europe. Politics and Religion, 4 (1), 1-26.

Oesch, D. 2006. Coming to grips with a changing class structure. International Sociology, 21 (2), 263-288.

Oesch, D. \& L. Rennwald. 2010. The class basis of Switzerland's cleavage between the New Left and the Populist Right. Swiss Political Science Review, 16 (3), 343-372. 
Semyonov, M., A. Glikman \& M. Krysan. 2007. Europeans' preferences for ethnic residential homogeneity: Cross-national analysis of response to neighborhood ethnic composition. Social Problems, 54 (4), 434-453.

Snijders, T.A.B. \& R.J. Bosker. 1999. Multilevel Analysis: An Introduction to Basic and Advanced Multilevel Modeling. London: SAGE.

Weßels, B. 2007. Discontent and European identity: Three types of Euroscepticism. Acta Politica, 42 (2), 287-306.

Westle, B. 2003. Europäische Identifikation im Spannungsfeld regionaler und nationaler Identitäten. Theoretische Überlegungen und empirische Befunde. Politische Vierteljahresschrift, 44 (4), 453-482. 